\title{
Educational, Epistemological and Methodological Considerations on Multicultural and Peace Education ${ }^{1}$
}

\author{
Zvi Bekerman \\ Hebrew University of Jerusalem \\ Zvi.bekerman@mail.huji.ac.il
}

\begin{abstract}
Based on the result of over a decade of studies I conducted at the Palestinian Jewish integrated bilingual schools in Israel I consider some foundational issues related to present practice and research in the field of multicultural and peace education. I argue that any contributions psychological perspectives might offer to the development of pedagogies that can reduce intergroup hostilities are insufficient and suggest the need to critically approach the concepts of self and identity, culture, multiculturalism, and the political organization of the nation-state if we aim at enhancing the outcomes of intergroup education, the strategies that may improve it, and its research.
\end{abstract}

\section{Introduction}

In the following I will consider some foundational issues related to present practice and research in the field of multicultural and peace education. These are the result of over a decade of studies I conducted at the Palestinian Jewish integrated bilingual schools in Israel (Bekerman, 2003, 2009b). These schools have been functioning in Israel for the last three decades. Six of these schools exist in the present with a population of just over one thousand students. The schools' main goal is to create an educational setting with a declared aim to reduce prejudice and encourage coexistence in a country, Israel, in which Palestinians and Jews study, for the most part, in segregated school systems both under the supervision of the Ministry of Education (Shwed, Shavit, Dellashi, \& Ofek, 2014).

Due to the impossibility of compartmentalizing the schools' aims as if multicultural/peace education could have an existence separate from other educational spheres, the present notes relate to wider paradigmatic topics in general education. I truly believe that without a critical examination of the concepts and conditions upon and within which modern education rests, multicultural/peace education efforts are doomed to replicate the same ills of society they were designed to correct.

In my research I have shown how the schools under investigation suffer from practices, perspectives, and expectations that, many times, may contradict their goals. In general I have pointed out that, at present, bilingual projects seem primarily to serve the political

${ }^{1}$ This chapter is a revised and extended version of chapter 12 on my book entitled The Promise of Integrated Multicultural and Bilingual Education. UK: Oxford University Press, 2016.

Journal of Contemporary Issues in Education, 2016, 11(1), pp. 19-35 
agendas of nation-states whose boundaries no longer represent clear-cut national identities and which are affected, at least in the West, by large waves of voluntary and involuntary migration. Although these agendas sometimes strive to promote the interests of minority groups and confront mainstream hegemonies, at other times they merely pay lip service to political correctness. In the best cases, bilingual initiatives do not seem to be achieving their goals; in the worst cases, they are oblivious to the reasons for their failure (Bekerman, 2005, 2009c, 2011).

I proposed that theoretical constructs may blind participants to the fact that language is not the only way by which the world is organized, nor is it the only route to social justice. Moreover, educational institutions need not be the first - nor the sole - places in which to achieve linguistic rights. Even when selected for that purpose, schools must be viewed against their wider background; they must not be allowed to promote the reification of unitary groups (ethnic/national/religious). In the end, it is concrete structural changes that will help end human suffering.

Regarding multiculturalism I suggested that the foundational rhetoric of the bilingual initiative promotes the transformation of power relations between minority and majority groups through the preservation of symmetry (Bekerman, 2004, 2009a). Showing that although this rhetoric played a large role in parents' decision to send their children to the schools, the parents still placed a great emphasis on academic achievement and measured the schools' success not in terms of their liberatory power but by their role in developing the children's ability to attain desirable positions in the bureaucracies of Western cultural traditions (Giroux, 1994; McLaren \& Baltodano, 2000). In terms of academic achievement, the schools seemed to fare well, but their success on the ideological multicultural level was less apparent if only because their goals were not fully clear beyond manifestoes.

Despite their commendable efforts to create respectful, humane relations between ethnic groups in a conflict-ridden area, the participants in the bilingual initiative were frustrated in their search for ways to counter the burdens of tradition and the shadow of the stateimposed, ideologically normative hegemony. Lacking ready-made curricular tools, teachers and administrators incorporated the familiar resources that support the segregated Israeli educational system. Thus the activities in the schools were influenced by the same representations and historiographies that comprised the participants' personal biographies, and the school activities were delimited by the surrounding political conditions (Bekerman \& Zembylas, 2012).

All in all I have shown that even when based on critical approaches, cross-cultural education fails to recognize the connection between the essentialist and reifying approach to identity and culture, and its larger sociopolitical context, the nation-state. The following discussion will explore this connection in more depth, emphasizing its effects on multicultural/peace education, its practice and research. 


\section{Furthering the Educational Critique}

Because traditional psychology positions individuals within a human framework that is largely static and inflexible (Billig, 1991; Brubaker \& Cooper, 2000; Harre \& Gillett, 1995), any contributions psychological perspectives might offer to the development of pedagogies that can reduce intergroup hostilities are insufficient. In spite of its name, social psychology, too, has been unable to transcend perspectives in which the individual as social becomes a group, and has neglected the need to contextualize and historicize its object of study (Bekerman, 1999; Howard, 2000; Huddy, 2001).

One possible solution may lie in combining theoretical perspectives that promote the conceptualization and evaluation of integrated education models that provide people with opportunities to explore their personal and social identities while reducing their antagonism toward the "other." These issues - the concepts of self and identity, culture, multiculturalism, and the political organization of the nation-state and its monologismare intimately connected and should be taken into consideration when analyzing the possible outcomes of intergroup education and the strategies that may improve it.

\section{The Monologic Self and Identity}

One of the main obstacles in moving in the direction hinted above still is a Western psychologized perspective. The Western perspective by which self and knowledge are abstracted from the knower's specific context, placing the object — rather than the observer - as the focal point, is called monologism. It is a worldview so prevalent that it is no longer assumed to be a perspective of choice but a fact of nature. The fallacy of this paradigmatic vision has hidden the forces involved in the social construction of the self and other, thereby enabling the Western self to deny both the other and dialogue, and to exist in glorious isolation (Sampson, 1993).

Nonetheless, we can confirm our experience as social creatures; we can recognize that we are better described as becoming than as established, as active and vital verbs than as internalized, static nouns. We see ourselves as dynamic, as formed according to situations and tasks as parents, teachers, and spouses. Etymology supports this view: "Persona" is an external mask and "individual" is that which cannot be abstracted from a complex entity.

Paradoxically, this view did not dominate the Western imagination through a slowly advancing platonic spirit of virtue and truth but through overworked modes of domination. Michel Foucault (Foucault, 1979) uncovers these modes, focusing on the "how of truth" rather than on "the what of it," and promoting a critique of power that treats it as an interactive and enabling action. Explaining how a process of conversion began at the end of the Middle Ages and evolved, Foucault traces how the power formerly concentrated in the figure of the ruler gradually diffused and was replaced by mechanisms that were measured rather than excessive, continuous rather than sporadic. Brutal direct power exercised by the unquestioned ruler could be clearly observed and 
identified; thus it slowly became hidden behind less obvious techniques of control that would, through careful examination, calibrate bodily activity, sound, position, posture, and cleanliness. By these methods power would be absorbed in each of us, establishing a sense of individuality without being itself diminished. Thus created and controlled the individual "I" became one of the cheapest and most successful means of domination. The panoptic penal regime is the site where ipseity (the sense of self) is ultimately settled:

...he who is subjected to a field of visibility, and who knows it, assumes responsibility for the constrains of power; he makes them play spontaneously upon himself; he inscribes in himself the power relation in which he simultaneously plays both roles; he becomes the principal of his own subjection. (Foucault, 1979, pp. 202-3)

Others (Gellner, 1983a; Giddens, 1991) explain how the rise of the nation-state resulted in a social structure that was radically different from those of the past, with forms of territoriality and surveillance capabilities that exerted control through monopolized violence. The nation-states' chief aim was to create a direct relationship between itself and all of its individual citizens. Neither tribe, ethnic group, family, nor church was allowed to stand between the "individual" citizen and the state (Mendus, 1989). The nation-state dominated the populations by establishing, through massive education, a culture that was simultaneously homogenous, anonymous, and universally literate (Gellner, 1983a).

An example of this process is seen in Mitchell's (1988) work on the colonialization of Egypt in which he describes how a Western presence and its political machine became established there, first using Prussian army tactics and then schooling to manufacture a Cartesian perspective that left no room for traditional notions of space, personhood, or epistemology. What had formerly been seen as chance events in the social realm was replaced by the orderly products of individual will, guided by reason. The body was operated by a mind that was a detached internal mechanism of true representation. The colonializing machinery in Egypt thus divided the world into the realm of things and the realm of order. Political power, presiding without ever quite being present within individual knowers, now rested in the realm of order of what was accorded significance. All material representations would henceforth go unnoticed.

The abstracted construct developed by nation-state politics and education is termed "the Cartesian self." The Cartesian self exists apart from contexts, its primary activitythinking (res cogitans) - is similarly detached from the body and from society, and its isolated mind is the only means by which knowledge of the outside world is achieved. From this perspective, individuals are separated from other individual selves who share these characteristics, and hence dialogue, the world's most "natural" experience, becomes a victim of the West's monologized epistemological certitude.

Similarly, individual and social identities have been described as the product of power relations that establish dichotomous hierarchies (Laclau, 1990) within which the powerful are considered "essential" while the weak are relegated to a subordinate category, (e.g. man/woman, Black/White, Jew/Palestinian). Historians, sociologists, and even 
psychologists (Billig, 1995; Gellner, 1983b; Giddens, 1991; Smith, 1979) have

expounded on the influence of the development of the nation-state and nationalism on longstanding conceptions of "identity." The massive educational efforts that market universal (anonymous) literacy within the nation-state have succeeded in rendering invisible the strategies by which the nation-states become a setting within which our individuality is measured against a contingent "other" (Laclau, 1990). Indeed, the nationstates' scheme has become so powerful that nationalism directs our most basic paradigmatic conceptions on a fixed individual identity, blinding us to the possibility of more flexible alternative perspectives.

\section{The Essentialized View of Culture}

Like identity, culture is reified as a reflection of the autonomous self: The internal, abstracted individual becomes social and material through enculturation. When the self is monologic, culture is objective and fixed, outside any dynamic and developing historical domains (Bekerman, 1999; Jahoda, 1988; McDermott, 1993; Sewell Jr, 2005). At times, culture is accomplished so autonomously in the eyes of theoreticians that it is perceived as acting on humanity in a process by which the "culturally imprisoned" individual is the target of educational interventions (McDermott \& Verenne, 1995).

Historically, however, culture is not an entity but a process, an infrastructure for growth, action, and perpetual human endeavor. The English word "culture" is derived from Latin cult and cultura-ae (Williams, 1961), meaning work, as in agriculture-working the field - as well as words in numerous languages referring to Divine worship. Examining the historical processes that led to the reification of this concept may shed light on the dangers inherent in non-critical application of the term, even in fundamentally "positive" movements such as multiculturalism.

In Culture and Society, Williams (1961) notes that towards the end of the eighteenth century, the word "culture" was accorded a distinct and abstract meaning to address two processes taking place in the developing national sovereign community. First, it reflected the Christian differentiation between moral and intellectual pursuits and the manufacture of products in a world of industrial development. Second, it became a human court transcending practical human judgment. This background is reflected in the definition of culture posited by British educator and philosopher Matthew Arnold: "The best which has been thought and said in the world," i.e. the best we have to learn and teach. This view allows for the distinction between "high" and "popular" culture, which largely blocks penetration of alien (i.e. non-hegemonic) cultural aspects into the ruling culture.

The nation-state contributed to the reification of culture by presenting culture as a closed system of values, texts, and ceremonies used to foster unity among inhabitants of a nation-state's territory (Elias, 1991; Williams, 1976). Through "culture," a nation-state could neutralize local communities' language and customs, subsuming them into those claimed for the national group. Furthermore, unmediated contact between members of this group and the state was facilitated through an all-consuming "national culture" in 
which citizens devoid of any affiliation with ethnic, national, or religious groups were entitled to prima facie political equality (Mendus, 1989). This equality, however, came at a cost. The cultural literacy that the state demanded of its citizens was determined by the elite who founded the state, and that literacy was not presented as particularistic but as universal, lofty, and exclusive. All residents, regardless of affiliation to their initial group's culture, were obliged to uphold it (Gellner, 1983a).

In short, "culture" is represented as an external reflection of an internal essentialized "identity." As such, similar to identity, when this reflective aspect is not accounted for it may merely reinforce the same reality they were intended to overcome.

\section{Institutionalized Education}

The above-mentioned perspectives constitute and are constituted in the daily routines of present educational structures that must be explored more deeply in order to expose the roots of the problems of educational initiatives geared towards coexistence. Formal education played a major role in the historical processes that brought about the tyranny of the nation-state. Like the industrial revolution, the nation-state required masses with cognitive and behavioral skills that could fill the needs of its economic structures. Schools are not disinterested arenas within which neutral knowledge or skills are transmitted from the minds of specialists to those of passive individuals but have served as the primary means by which sovereigns have unified the local area groups under one flag, one language, and one narrative.

It is surprising that peace-searching groups in society have so often chosen educational institutions to advance their goals of coexistence; yet, it could be argued that these groups adapt existing structures to serve their own purposes and not just those of the nation. Nonetheless, the lynchpins of schooling's success are its structure and functionality, both of which stem from a paradigmatic perspective that has nothing to do with reconciliation. In fact, schools are the prime conduit for the transmission of the two interrelated beliefs of the Western world that were discussed above, the belief in the individual self and the outside existence of knowledge (culture). With regard to schooling, form follows function, as can be seen in the following three characteristics of the structure of modern schools (Goody, 1987; Cole, 1990):

- The student was trained by strangers, separated from his kin and family.

- The knowledge slated for transmission was differentiated and compartmentalized into fields of specialization.

- Learning took place outside the context of its intended implementation.

When knowledge is segregated from the places in which it can be functional and when it does not reflect that which is useful in the outside world, learning does not become relevant to students. For encounter groups striving for coexistence, the disparity of methods and goals may prove to be an insurmountable obstacle. Can a framework premised on distancing the individual from family and community serve to engender peace perspectives that challenge those accepted in society? Can a structure that presents knowledge in compartmentalized chunks (history, physics, civics, peace, etc.) cultivate a 
holistic vision of coexistence in the world? Programs that seek to strengthen recognition of other cultures and offer peace-making as response to real sociocultural-political issues may conclude that institutional educational structures and procedures are not conducive to achieving these aims (Bekerman, 2007).

The unchallenged principles that underlie education efforts explain why multicultural/peace education is unable to help groups in conflict realize their goals. The following section will consider options to strengthen education's potential to support coexistence and reconciliation in light of the critiques discussed above.

\section{Reframing Multicultural/Peace Education}

As has been shown, many of the problems of multicultural/peace education result from the "epistemological primacy" of the underlying assumptions of identity and culturethat is, the normative epistemology used to justify the naturalization of identity and culture within nation-states - and the anchoring of these assumptions in educational structures. The purpose of this section, in line with what has recently come to be identified as the 'ontological turn' in philosophy and the social sciences (Escobar, 2007; Kivinen \& Piiroinen, 2004; Paleček \& Risjord, 2013; van Dijk \& Withagen, 2014), is to illustrate the importance of moving from the epistemological to the ontological, while describing and analyzing the consequences of this move for multicultural/peace education and how it might be implemented. The goal is to open a long overdue debate over a question that resonates in general education as well as multicultural/peace education: What does it mean for multicultural/peace education to examine critically the historicized and contextual nuances of conflict and peace?

\section{Critical Experts of Design}

We suggest that developing educational strategies to improve coexistence requires that we first help participants become critical experts of design so they can problematize the interdependent relationship between the reified concept of identity/culture and the political organization of the nation-state. A process of externalizing narratives will reveal what the nation-state presents as psychologized and inaccessible to observers.

Scrutinizing societal interactional details can demonstrate that nationalism, racism, and patriotism do not originate in people's heads but are erected there through popular culture, social practices, and school ceremonies at considerable cost. Though difficult and sensitive educational work, exposing the practices that are usually assumed to be internally performed by and natural to individuals is the only path by which we can identify those strategies against which our struggle should be directed.

Any potential solution necessitates a radical change in educators' worldviews. Educators must replace their focus on the student's individual mind with a focus on the interactional strategies through which identity and culture make their appearance, according to criteria that are "objective" without resting on the positivist underpinnings of objectivism. Such 
criteria could be achieved through questioning: Who in our societal context are exploited? Who are the powerful and who the powerless? Which cultural patterns carry symbolic power (Hames-Garcia, 2000)? Who are labeled as the "others"? Which categories are used and who defines them? How and when are they applied?

This process of questioning is consistent with a cultural analysis perspective (Varenne \& McDermott, 1998) that proposes we learn to read the world through careful observation and recording of practical activity, being open to finding new criteria through which to name categories and their phenomena. This outlook allows for a shift from using the individual or the socializing group as the analytic unit to using the mechanisms by which cultural contexts are produced through social interaction. Ideally, such a process will lead to policy issues that are no longer linked to culture and its components but to the analysis of particular identities/cultures and how they are molded in the particular context of particular societies. Through its implication that identity/culture are not necessarily the right criteria through which to describe the world, cultural analysis suggests that while identity and culture may be legitimate constructs (however hegemonic), they need not result in individual suffering.

Adopting this new perspective involves offering students literacies with which to evaluate the world, literacies that require abundant theory and rich descriptive faculties to cope with the complexity of the sites and social phenomena students will encounter. Thus they need familiarity with an economic discourse for discussing commodities, supplies, and management; an aesthetic discourse to discuss architecture, advertising, and display; a political discourse to discuss policies, planning, and discipline; and a historical discourse to talk about change in organization, consumption, and community. They also need interpretative discourses to articulate understandings of the texts and intertextuality, which, in concert, create culture. These tools are necessary for a deep understanding of the hegemonic systems that currently hold sway. What is criticized in the system should not be viewed as the mistakes of the curriculum designers but as the "achievements" of a system that wants to sustain conflict in order to sustain the power of the nation-state. Therefore, the better our tools of analysis, the deeper our understanding of the details of the system and the more we know about possibilities for change. As we move from psychologized perspectives of education toward the material details of conflict and peace, the potential for change grows.

A student should not be labeled with ethnic, national, or racial labels. Rather, attention must be directed toward those spheres of localized interactions in their historical trajectories through which categories like "Palestinian" and "Jewish" are enabled. We should be aware of the ways through which teachers/curriculum/society ask questions, give feedback, speak the "correct language" and decide on the criteria for identifying "Jewish" and "Palestinian" students. The struggle for nation-building in our schools, the discourse of individuality in our media, and the unequal distribution of resources in our society have to be identified, described, and offered to all participants as tools through which desired changes can be made. 
These activities imply a return to children's perspectives that do not depend on prepacked categories to organize the social world. Children appear able to organize subcultures that are free to develop with no high disciplinary cost. Adults at times rejoice in children's normative mistakes, at least in areas they believe "time will correct," such as language pronunciation. However, Western psychologized perspectives turn children towards adulthood like novices avidly learning to become "old." Research has demonstrated the compelling subcultures children organize (Harris, 1998; Hirschfeld, 2002); adults need to consider that sustaining and supporting these cultures offers the possibility of overcoming society's greatest ailments.

In summary, critical pedagogy can take the following steps to achieve a new orientation in the contexts we have discussed. First, teachers and students as critical experts of design need to base programs for developing community relations around an exploration of the roles of identity and culture in real life. Second, they need to challenge the notion that identity and culture are appropriate categories for describing the world. Third, they must develop the skills of cultural analysis rather than accumulating "knowledge" of the characteristics of the "other"; that is, they should not start with the "other" as a given but with collaborative processes that dismantle existing categories. Finally, efforts need to be redirected from a focus on the "other" to collaborative efforts toward making a better world (Bekerman, 2009a).

\section{A Critique of the Social Sciences Research Cultural Milieu}

In this last section I critically approach research in the social sciences more specifically, though not only, that which is conducted hoping to contribute to educational practice in conflict-ridden societies.

I first point at the need of research in the social sciences to realize it has surrendered its analytical scope to methodological nationalism. Second, I point at the necessity to review its epistemological colonialism (Poulter, 2012) — its secular rational underpinnings — and how these might influence the researchers' understanding of traditional cultural/religious phenomena which in no small part is the phenomena they are trying to understand. These two methodological considerations are discussed below to show how they are entangled with educational efforts to overcome strong attachments to identity and cultural categories.

Methodological nationalism is the naturalization of the global regime of nation-states by the social sciences (Beck, 2000; Wimmer \& Schiller, 2003). It expresses itself every time scholars take for granted concepts which should be identified as being folkloristic or political and not necessarily analytical in their studies and research. In this sense countries are not natural entities, societies are not necessarily countries organized as states, and minorities/immigration are not the flow in or between nations. Adopting methodological nationalism as an intellectual orientation in the study of the social sciences blinds research to the profound influence of the political organization of the nation state in shaping present realities; such an orientation compartmentalizes

Journal of Contemporary Issues in Education, 2016, 11(1), pp. 19-35 
phenomena into units of analysis that otherwise should be considered in wider contexts and consequently sets national boundaries for social phenomena which otherwise should be approached focusing also on wider contexts.

As the political context of the nation state is not bounded, the individual and his or her culture are not bounded either; when the social sciences uncritically surrender to conceptualizations such as identity and culture, without attending to the potential dangers of naturalizing folkloristic concepts while embedding them in analytical discourses, they risk hiding the phenomena they intend to uncover.

As for its epistemological colonialism theoreticians have pointed at it as suspicious for holding to the same values it criticizes in the cultural/religious realm. Secularism has been approached by critical theoreticians (Abeysekara, 2008; Asad, 2003) as a modern doctrine while others characterize it as a form of apartheid (King, 2009), or "epistemological racism" (Maldonado-Torres, 2004).

When focusing on the civic and the multicultural in education, the conjunction of secular liberalism and imperialism is not entirely new (Mehta, 1999, cited in Kundnani, 2012). This arrogant liberal position is expressed in integrationist policies which divide populations into those who are true citizens, and those in need of 'civilizing process' that refashions their values so as to be able to become citizens. The political techniques, the so called "rituals of humiliation" (McVeigh \& Rolston, 2009) promoted by liberal integrationists to produce "co-opted" citizens - oaths of allegiance, requirements to declare one's rejection of extremist ideas, swearing loyalty to a set of national values, tests of 'values' acquisition, the erasure of one's own experience and history in favor of the public celebration of national history — all have a long history in colonialism (Kundnani, 2012).

Religious/cultural epistemologies (which are linked to the civic, the communal) emerge then as embedded in particular socio-historical and cultural contexts and are represented and interpreted within the frames made available by the hegemonic formations discussed above. In the west the civic, often, masquerades the religious. It should come then as no surprise that migrants and minorities express distrust and/or sense a strong clash between, their unarticulated perception, civic religious western perspectives and their own cultural/religious traditions; so is the case to for the majority.

Cultural/religious epistemologies, as other private epistemologies, have implications for all dimensions of life as they speak to what counts as knowledge and how knowledge is constructed and evaluated (Hofer, 2004). Epistemologies include beliefs about the stability of knowledge (ranging from unchanging knowledge to tentative knowledge), the structure of knowledge (ranging from small bits to integrated concepts), the source of knowledge (ranging from omniscient authority to empirical evidence) and the stability of knowledge (which includes the ability to learn and to change previous knowledge) (Schommer-Aikins, 2004). Epistemological beliefs are often unreflected, they are 'comfortable' and not easy to change, and their general fuzziness adds to the challenge of 
addressing them (Schommer, 1994). This might partially help explain the essentializing tendency found even in those who hold to cultural sensitive perspectives.

Students who hold these epistemologies are often judged as irrational, pre-modern, or anti-Western by their Western mostly secular peers and teachers (Gottlieb, 2008). However, as research has shown, the developmental progression of epistemological reasoning from pre-reflective (including religious reasoning) to reflective thinking (seeing knowledge as constructed) posited by early research is not as linear as it had been assumed (Kuhn, Cheney, \& Weinstock, 2000). Research shows that cognitively sophisticated and mature individuals subscribe to religious epistemological beliefs that would have been described as immature or naïve by early research (Gottlieb, 2008).

There is a great variability of how people of different ages reason (King \& Kitchener, 2004) and cultural/religious epistemologies are included in this variability, independent of intellectual ability or maturity. Hence, from a developmental perspective, there is no age norm and cultural/religious epistemologies cannot be simply ignored as pre-modern, backward, or even delayed.

Needless to say that when embarking on a study of the cultural/religious/civic epistemologies of minorities, and majorities too, it is of utmost importance to differentiate between those perspectives which consider cultural/religious epistemologies as being relatively stable belief systems (diSessa, 1993; McCloskey, 1984; Smith, diSessa, \& Roschelle, 1993) and more contemporary interpretive practices that reflect an understanding of these epistemologies as representing a wide spectrum including the questioning of traditional interpretations and the engagement with critical debate.

We posit that, as today's cultures and epistemologies begin to mingle and translation between them becomes inevitable (Isin, 2012), what is ideally required is "an interactive concept of knowledge and understanding that reflects on the very process of constructing (e.g. putting in order) that portion of the world to be known" (Mignolo, 1995/2003, p. 15). Entailed in this process is the collaborative negotiation of new conceptions of what counts as legitimate knowledge in the public sphere and its institutions and how this knowledge is linked to notions of citizenship and multiculturalism. This process may include "undoing knowledge" as it involves "deorientalizing" and "decolonizing" the ways in which legitimate knowledge has been instituted through social sciences" scientific practices (Mignolo, 1995/2003); "uncovering knowledge" that has been masked and disqualified by hegemonic discourse (Foucault, 1980); and "reinventing knowledge" which includes forging new conceptions of unconcealed knowledges (Isin, 2012; Mignolo, 2009). All three are directly linked to understandings of who has the right to speak as citizen, and how, and with this they speak to ways in which civic identities can be enacted through creative micro-acts of citizenship while not focusing only on minority/migrant "cultures".

Once freed from the tyranny of identity and culture, people's affiliation with a group is not a matter of identity but of identification fashioned as an exercise conducted with 
one's partners and neighbors (Carbaugh, 1996; Varenne \& McDermott, 1998). Depending on the historical and social scene, the same behavioral pattern may give rise to different kinds of group identification. Viewed through this lens, being a Jew or a Palestinian is not destiny but achievement, attained with the permission of partners through activities carried out in a particular place at a particular moment in history. Beliefs, views, and especially scenarios involving parents, teachers, and multiple other social interactants - supporters and detractors alike - are participants in the process of identification. "Palestinian" and "Jew" are not characteristics in people's minds but the results of work accomplished in the scenes in which these characteristics exist. All of the above is a renewed invitation to the social sciences to first acknowledge and second confront complexity.

By making our analysis more inclusive adding to the traditional attempt to recognize and legitimate the others cultural practice the analysis of our own cultural political milieu and its immediate outcomes, we might be able to open a better dialogue in which we all become suspects but as well possible collaborators not in defending an inexistent fixed culture/identity but instead in the work of shaping a better present.

Finally, multicultural/peace education should seek solutions in the organization of Western world politics rather than in the parameters of school settings. There are limits to what an educational system can do, for example, to offer symmetry. In the broader societal context, however, claims for symmetry are often linked to demands for recognition. Exchanges can be offered when other forms of symmetry are impossible (e.g. for-giveness, which begets forgetting, and reparations when lives cannot be returned, or monetary compensation when returning territories is too complex). Educational systems can suggest the complexities involved in demands for symmetry but they are not in a position to advocate for it in the absence of accommodating political decisions and structures.

Varenne and McDermott (1998) challenge our concept of difference by asking: In what ways and for what purposes is it useful to speak of "difference" between people who have spent two or three hundred years living and working together in the same valley, who have lived the same history (p. 151)? Could such differences merely be the historical product of interaction within a common cultural evolution? And even if one is to accept that individuals are the products of their community, what are the boundaries of that community? For our purposes, boundaries are the product of the people who must pay attention to them, both those who enforce them and those who try to sneak around them. Boundaries and other spaces are artifacts of history, the products of culture as it makes conditions by which human action must abide. They are constructed and because of this, though with difficulty, might be also deconstructed. 


\section{References}

Abeysekara, A. (2008). The politics of postsecular religion: Mourning secular futures. New York: Columbia University Press.

Asad, T. (2003). Formations of the secular: Christianity, Islam, modernity. Stanford: Stanford University Press.

Beck, U. (2000). What is globalization? Cambridge: Polity Press.

Bekerman, Z. "The Hebrew Language - a Constructive Language for Jewishness Sometimes." In Present and Future: Jewish Culture, Identity and Language, edited by David Zisenwine and David Schers, 101-27. Tel Aviv: School of Education - Tel Aviv University, 1999.

Bekerman, Z. (2003). Palestinian Jewish bilingual education in Israel: Its influence on school students. Journal of Multilingual and Multicultural Development, 24(6), 473-484. http://dx.doi.org/10.1080/01434630308666511

Bekerman, Z. (2004). Potential and limitations of multicultural education in conflictridden areas: Bilingual Palestinian-Jewish schools in Israel. The Teachers College Record, 106(3), 574-610. http://dx.doi.org/10.1111/j.14679620.2004.00351.x

Bekerman, Z. (2005). Complex contexts and ideologies: Bilingual education in conflict-ridden areas. Journal of Language, Identity, and Education, 4(1), 1-20. http://dx.doi.org/10.1207/s15327701jlie0401_1

Bekerman, Z. (2007). Rethinking intergroup encounters: Rescuing praxis from theory, activity from education, and peace/co-existence from identity and culture.

Journal of Peace Education, 4(1), 21-37. http://dx.doi.org/10.1080/17400200601171198

Bekerman, Z. (2009a). Identity vs. peace: Identity wins. Harvard Educational Review 79(1), 74-83. http://dx.doi.org/10.17763/haer.79.1.m30672027u72x633

Bekerman, Z. (2009b). Social justice, identity politics, and integration in conflict ridden societies: Challenges and opportunities in integrated Palestinian-Jewish education in Israel. In W. Ayers, T. Quinn, \& D. Stovall (Eds.). Handbook of social justice in education (pp. 138-151). New York, NY: Routledge.

Bekerman, Z. (2009c). Yeah, it is important to know Arabic-I just don't like learning it': Can Jews become bilingual in the Palestinian Jewish integrated bilingual schools. In C. McGlynn, M. Zembylas, Z. Bekerman, \& T. Gallagher (Eds.). Peace education in conflict and post-conflict societies: Comparative perspectives (pp. 231-246). New York, NY: Palgrave Macmillan.

Bekerman, Z. (2011). Integrated bilingual education: Ethnographic case studies from the Palestinian-Jewish 'front'. C. Hélot, \& M. Ó Laoire (Eds.). Language policy for the multilingual classroom: Pedagogy of the possible (pp. 188-208). Bristol, Buffalo, Toronto: Multilingual Matters.

Bekerman, Z., \& Zembylas, M. (2012). Teaching contested narratives: Identity, memory and reconciliation in peace education and beyond. Cambridge, UK: Cambridge University Press.

Journal of Contemporary Issues in Education, 2016, 11(1), pp. 19-35 
Billig, M. (1991). Ideology and opinion: Studies in rhetorical pschology. London: Sage Publications.

Billig, M. (1995). Banal nationalism. London: Sage.

Brubaker, R., \& Cooper, F. (2000). Beyond "identity". Theory and Society, 29(1), 147. http://dx.doi.org/10.1023/A:1007068714468

Carbaugh, D. (1996). Situating selves: The communication of social identities in American scenes. Albany: SUNY Press.

Cole, M. (1990). Cultural psychology: A once and future discipline? In J. J. Berman (Ed.). Nebraska Symposium on Motivation, 1989: Cross-Cultural Perspectives (pp. 179-335). Lincoln: University of Nebraska Press.

diSessa, A. (1993). Toward an epistemology of physics. Cognition and Instruction, 10(2/3), 105-225. http://dx.doi.org/10.1080/07370008.1985.9649008

Elias, N. (1991). The society of individuals (E. Jephcott, Trans.). Oxford: Blackwell.

Escobar, A. (2007). The 'ontological' turn in social theory. A commentary on 'Human geography without scale', by Sallie Marston, John Paul Jones II and Keith Woodward. Transactions of the Institute of British Geographers, 32(1), 106111. http://dx.doi.org/10.1111/j.1475-5661.2007.00243.x

Foucault, M. (1979). Discipline and punish: The birth of the prison. New York: Random House.

Foucault, M. (1980). Power and knowledge: Selected interviews and other writings 1972-1977. New York: Pantheon Books.

Gellner, E. (1983a). Nations and nationalism. Oxford: Basic Blackwell.

Gellner, E. (1983b). Nations and nationality. Oxford: Basic Blackwell.

Giddens, A. (1991). Modernity and self-identity. Stanford CA: Stanford University Press.

Giroux, H. (1994). Doing cultural studies: Youth and the language of pedagogy. Harvard Educational Review, 64(3), 278-308. http://dx.doi.org/10.17763/haer.64.3.u27566k67qq70564

Goody, J. (1987). The interface between the written and the oral. Cambridge: Cambridge University Press.

Gottlieb, E. (2008). Arguments as venues for cultural education: A comparison of epistemic practices at general and religious schools in Israel. In Z. Bekerman, \& E. Kopelowitz (Eds.). Cultural education - cultural sustainability: Minority, diaspora, indigenous, and ethno-religious groups in multicultural societies (pp. 285-303). New York and London: Routledge.

Hames-Garcia, M. R. (2000). Who are our people? Challenges for a theory of social identity. In P. M. L. Moya, \& M. R. Hames-Garcia (Eds.). Reclaiming identity (pp. 102-132). Berkeley: University of California Press.

Harre, R., \& Gillett, G. (1995). The discoursive mind. London: Sage.

Harris, J. R. (1998). The nurture assumption: Why children turn out the way they do. New York; NY: Free Press.

Hirschfeld, L. A. (2002). Why don't anthropologists like children? American Anthropologist, 104(2), 611-627.

Hofer, B. K. (2004). Exploring the dimensions of personal epistemology in differing classroom contexts: Student interpretations during the first year of college.

Journal of Contemporary Issues in Education, 2016, 11(1), pp. 19-35 
Contemporary Educational Psychology, 29, 129-163.

http://dx.doi.org/10.1016/j.cedpsych.2004.01.002

Howard, J. A. (2000). Social psychology of identities. Annual Review of Sociology, 26, 367-393. http://dx.doi.org/10.1146/annurev.soc.26.1.367

Huddy, L. (2001). From social to political identity: A critical examination of social identity theory. Political Psychology, 22(1), 127-156. http://dx.doi.org/10.1111/0162-895X.00230

Isin, E. F. (2012). Citizenship after orientalism: An unfinished project. Citizenship Studies, 16(5-6), 563-572. http://dx.doi.org/10.1080/13621025.2012.698480

Jahoda, G. (1988). Critical notes and reflections on 'social representations'. European Journal of Social Psychology, 18(3), 195-209. http://dx.doi.org/10.1002/ejsp.2420180302

King, P. M., \& Kitchener, K. S. (2004). Reflective judgment: Theory and research on the development of epistemic assumptions through adulthood. Educational Psychologist, 39(1), 5-18. http://dx.doi.org/10.1207/s15326985ep3901_2

King, R. (2009). Philosophy of religion as border control: Globalization and the decolonialazation of the "love of wisdom". In P. Bilimoria, \& A. B. Irvine (Eds.). Postcolonial philosophy of religion (pp. 35-54). Dordrecht: Springer. http://dx.doi.org/10.1007/978-90-481-2538-8_3

Kivinen, O., \& Piiroinen, T. (2004). The relevance of ontological commitments in social sciences: Realist and pragmatist viewpoints. Journal for the Theory of Social Behaviour, 34(3), 231-248. http://dx.doi.org/10.1111/j.00218308.2004.00246.x

Kuhn, D., Cheney, R., \& Weinstock, M. (2000). The development of epistemological understanding. Cognitive Development, 15, 309-328. http://dx.doi.org/10.1016/S0885-2014(00)00030-7

Kundnani, A. (2012). Multiculturalism and its discontents: Left, Right and liberal. European Journal of Cultural Studies, 15(2), 155-166. http://dx.doi.org/10.1177/1367549411432027

Laclau, E. (1990). New Reflections on the revolution of our time. London: Verso.

Maldonado-Torres, N. (2004). The topology of being and the geopolitics of knowledge: Modernity, empire, coloniality. City: Analysis of Urban Trends, Culture, Theory, Policy, Action, 8(1), 29-56. http://dx.doi.org/10.1080/1360481042000199787

McCloskey, M. (1984). Naive theories of motion. In D. Gentner, \& A. Stevens (Eds.). Mental models (pp. 289-324). Hillsdale, NJ: Lawrence Erlbaum.

McDermott, R. (1993). The acquisition of a child by a learning disability. In S. Chaiklin \& J. Lave (Eds.). Understanding practice (pp. 269-306). Cambridge: Cambridge University Press. http://dx.doi.org/10.1017/CBO9780511625510.011

McDermott, R., \& Verenne, H. (1995). Culture as disability. Anthropology and Education, 26(3), 324-348. http://dx.doi.org/10.1525/aeq.1995.26.3.05x0936z

McLaren, P., \& Baltodano, M. P. (2000). The future of teacher education and the politics of resistance. Teaching Education, 11, 47-60. http://dx.doi.org/10.1080/10476210050020363

Journal of Contemporary Issues in Education, 2016, 11(1), pp. 19-35 
McVeigh, R., \& Rolston, B. (2009). Civilising the Irish. Race and Class, 51(1), 2-28. http://dx.doi.org/10.1177/0306396809106160

Mendus, S. (1989). Toleration and the limits of liberalism. New York: Macmillan. http://dx.doi.org/10.1007/978-1-349-20056-6

Mignolo, W. D. (1995/2003). The darker side of the renaissance: Literacy, territoriality, and colonization. Ann Arbor, MI: The University of Michigan Press.

Mignolo, W. D. (2009). Epistemic disobedience, independent thought and decolonial freedom. Theory, Culture \& Society, 26(7-8), 1-23. http://dx.doi.org/10.1177/0263276409349275

Mitchell, T. (1988). Colonising Egypt. Cambridge: Cambridge University Press.

Paleček, M., \& Risjord, M. (2013). Relativism and the ontological turn within anthropology. Philosophy of the Social Sciences, 43(1), 3-23. http://dx.doi.org/10.1177/0048393112463335

Poulter, S. (2012). From secular epistemology towards the pedagogy of 'interknowledges'. Muslim Education Quarterly, 25(3/4), 19-30.

Sampson, E. E. (1993). Celebrating the other: A dialogic account of human nature. Hertfordshire: Harvester Wheatsheaf.

Schommer-Aikins, M. (2004). Explaining the epistemological belief system: Introducing the embedded systemic model and coordinated research approach. Educational Psychologist, 39(1), 19-29. http://dx.doi.org/10.1207/s15326985ep3901_3

Schommer, M. (1994). An emerging conceptualization of epistemological beliefs and their role in learning. In R. Garner, \& P. A. Alexander (Eds.). Beliefs about text and instruction with text (pp. 25-40). Hillsdale, NJ: Lawrence Erlbaum Associates, Inc.

Sewell Jr, W. H. (2005). The concept (s) of culture. In G. M. Spiegel (Ed.). Practicing history: New directions in historical writing after the linguistic turn (pp. 7695). New York: Routledge.

Shwed, U., Shavit, Y., Dellashi, M., \& Ofek, M. (2014, December 17). Integration of Arab Israelis and Jews in schools in Israel. Taub Center for Social Policy Studies in Israel. Retrieved from: http://taubcenter.org.il/integration-of-arabisraelis-and-jews-in-schools-in-israel/

Smith, A. (1979). Nationalism in the twentieth century. New York: New York University Press.

Smith, J. P., diSessa, A. A., \& Roschelle, J. (1993). Misconceptions reconceived: A constructivist analysis of knowledge in transition. The Journal of the Learning Sciences, 3(2), 115-163. http://dx.doi.org/10.1207/s15327809j1s0302_1

van Dijk, L., \& Withagen, R. (2014). The horizontal worldview: A Wittgensteinian attitude towards scientific psychology. Theory \& Psychology, 24(1), 3-18. http://dx.doi.org/10.1177/0959354313517415

Varenne, H., \& McDermott, R. (1998). Successful failure: The school America builds. Colorado: Westview Press.

Williams, R. (1961). Culture and society, 1780-1950. Hardmondsworth: Penguin Books.

Journal of Contemporary Issues in Education, 2016, 11(1), pp. 19-35 
Williams, R. (1976). Keywords: A vocabulary of cultural and society. New York: Oxford University Press.

Wimmer, A., \& Schiller, N. G. (2003). Methodological nationalism, the social sciences, and the study of migration: An Essay in historical epistemology. International Migration Review, 37(3), 576-610. http://dx.doi.org/10.1111/j.1747-7379.2003.tb00151.x 